\title{
The Relation between Financial Literacy, Financial Wellbeing and Financial Concerns
}

\author{
Marzieh Kalantarie Taft ${ }^{1}$, Zare Zardeini Hosein ${ }^{2}$, Seyyed Mohammad Tabatabaei Mehrizi ${ }^{3}$ \& Abdoreza Roshan ${ }^{4}$ \\ ${ }^{1}$ Department of Accounting, Faculty of Humanities, Yazd Islamic Azad University, Iran \\ ${ }^{2}$ Department of Management, Ferdowsi University of Mashhad, Mashhad, Iran \\ ${ }^{3}$ Islamic Azad University, Science and Research Branch, Tehran, Iran \\ ${ }^{4}$ Imam Hosein University, Faculty of Humanities, Tehran, Iran \\ Correspondence: Zare Zardeini Hosein, Department of Management, School of Administrative \& Economic \\ Science, Ferdowsi University of Mashhad, Mashhad, Iran. E-mail: Hzare622@gmail.com
}

Received: February 21, 2013

Accepted: March 27, $2013 \quad$ Online Published: May 16, 2013

doi:10.5539/ijbm.v8n11p63

URL: http://dx.doi.org/10.5539/ijbm.v8n11p63

\begin{abstract}
Increased variety of products and the instability of the global economy in twenty first century caused increasing complexity of financial decisions and also caused consumers faced with the challenge in economic and financial activities. For this reason, in the last decade, the importance of financial management skills in personal and work life has increased and researches in this area has been done. In this regard, this study tries to evaluate the relation between financial literacy, financial wellbeing and financial concerns. For this purpose, a questionnaire was designed and distributed using random sampling among people. Data was analyzed using correlation test, Independent two-sample test based on the $\mathrm{T}$ distribution and regression. The results showed that age and education are positively correlated with financial literacy and financial wellbeing. Married people and men are more financially literate. Higher financial literacy leads to greater financial well-being and less financial concerns. Finally, financial wellbeing leads to less financial concern.
\end{abstract}

Keywords: financial literacy, financial wellbeing, financial concerns, economic stress, financial management

\section{Introduction}

From the early to mid twentieth century, usually the trading volume was less and financial decisions were simple and easy. With the advent of the Industrial Revolution and the increasing volume and variety of goods, the size and diversity of the world's trade was gradually increasing and following it, developing communications network, sales were facilitating and spending was soared. Such circumstances led to the increasing complexity of financial management and hardening financial decisions in the past few decades (National Institute of Financial Education of America, 2010). Also over the past decade the stability of the world economy has declined and recession has caused increasing inflation and unemployment and reducing communities' income. Complexity of financial decisions and economic recession has threatened the quality of people's individual lives and work and has made researchers to investigate ways to deal with them. Financial wellbeing and financial concerns are two important factors determining the quality of life and has been investigated in several studies. Recession has threatened the financial well-being and caused economic concerns, including concerns about health, debts, income and career advancement in the world. These concerns have harmful effects on psychological and physical health, reduce confidence and productivity in the workplace and increase absenteeism, delays, lack of concentration as well as conservative (Godfrey, 2006; Van Praag et al., 2003).

One of the issues that can help in terms of complexity and recession and could have a positive effect on economic capability is financial literacy. Financial literacy means the ability to understand and analyze financial options, planning for the future, and responding appropriately to the events. Having the ability has influence on the conditions of life and work and can be very helpful in anticipating the future and increasing human income. Unfortunately, despite the importance of financial literacy, research has shown that this ability among the people of the world, especially in developing and underdeveloped countries is not perfect and barriers such as the complexity of financial life, the existence of many options when making decisions and having not enough time and money to learn about personal finance issues, caused low financial literacy of people in these communities 
(Vitt et al., 2000).

Several studies have been conducted with the subject of financial wellbeing, financial concerns, and financial literacy. In these researches, the impact of three variables on financial decisions, health and success in business and personal life of individuals was covered and family factors, economic-social and demographic variables on the rates of economic welfare, financial concerns, and financial literacy are studied. One of the gaps in the research literature is the absence of study in which three variables related to financial wellbeing, financial literacy and financial concerns are considered. In this regard, this study will attempt to measure the three variables and investigate their relationship. This research can help fill this gap in the research literature.

\section{Literature Review}

\subsection{Financial Literacy}

Different definitions of financial literacy and personal finance are presented in the literature until now. Garman and forgue (2000) have identified financial knowledge as understanding the principles and terminology needed for a successful management of personal financial issues. Jacob et al (2000) considered personal financial knowledge as concepts of personal financial management skills and information. They have considered the meaning of word knowledge as knowing conditions, practices, rules and norms required for performing financial duties. The term financial involves a wide range of daily activities that are associated with the funds and includes activities such as check control to credit card management, budget preparation, purchasing insurance and investment. According to Remund (2010), financial literacy is a person's ability to understand and use financial matters. Huston (2010) considers financial literacy including awareness and knowledge and financial instruments and their application in business and personal life. In general, these definitions show that financial literacy includes the ability to balance a bank account, budget preparation, save for the future and learn strategies to manage debt. A person is known as financial literate if he/she is able to manage his/her personal finance in life and changing society in order to which he/she must achieve necessary perception, develop his/her skills in this area and be able to understand the impact of individual's financial decisions on his/her own, others and the environment (Remund, 2010).

The dependence of market boom to aware consumers, increased economic security and financial well-being of communities by increasing consumer awareness, sophisticated financial markets and increased risks of financial decisions have led to financial literacy beings known as one of the most important needs of human-being throughout the world (Hogarth, 2006). The significance is as much that the president of America signed an order in January 2008 to create a state advisory council on financial literacy and awareness of citizens in America. The goal of this council was making researches on the issues of financial knowledge, standards establishment for public awareness of financial issues and assist schools in providing appropriate training in this area (National Institute for Financial Education of America, 2010).

Increased financial literacy has a positive impact on people's personal and business life. The financial knowledge helps reducing social and psychological pressures and increasing the welfare of the family in the personal life. Financial knowledge reduces stress, illness, financial disputes, abuse of children and conflict among the families. People grown up in families with the higher financial knowledge and well-being are less depressed, show less aggressive and anti-social behavior and have more self-confidence (Fox et al., 2005). In work life higher financial literacy has higher efficiency and productivity in result and will help employees to better understand benefits offered by the organization and improve their satisfaction (Brennan, 1998). According to Champoin (2001), financial education cause reducing the absences in organization and keeping valuable employees. According to Kim (2007), high financial literacy decreases emotional stress and anxiety in the workplace. Bernheim and Garrett (2003) suggest in their study that the organizations strengthen their human resource management and promote the private and work life of their employees, increasing their employee's knowledge in the field of financial. According to Vitt et al. (2000), the greatest advantage of financial literacy education is reducing employees' financial problems and encouraging them to be responsible for their own financing and both will help increasing the efficiency of the organization.

\subsection{Financial Well-Being}

Wellbeing is a multi-part concept. According to Van Praag et al. (2003), well-being is provided by individual satisfaction in six areas: business, finance, home, leisure, health and environmental. McGregor and Goldsmith (1998) recognize welfare as including economic, physical, social, emotional, environmental aspects, political and spiritual factors. As mentioned in both references, material well-being is one of the aspects of welfare and convenience. Fergusson et al. (1981) describe financial wellbeing as financial income level and asset. Williams (1983) recognizes financial wellbeing as a function of material and spiritual aspects of one's financial status, 
and the Hayhoe et al. (1990) defined the financial well being as satisfaction feeling of a person with his financial status. According to Porter (1990) the financial well-being is one's attitude toward the financial status based on objective aspects and judge them with regard to the standards. According to Joo (1998) the concept of wellbeing or in other words people's perception of well-being varies with change in the level of people life. In the past, wellbeing has had the meaning of overall happiness or satisfaction with their financial status or assets. But at the present the wellbeing concept has changed to material and non-material aspects of a person's perception from their financial status, improving their living standards and includes perceptions such as: ability to meet the needs, feeling safe, feeling comfortable and satisfied with the income and the award distribution system. Goldsmith (2000) knows financial wellbeing as financial adequacy and safety of individual or family that protects the person against economic risks such as unemployment, illness, bankruptcy, poverty and destitution in retirement. As these definitions indicate, attitude towards the financial well being is different among researchers and in different studies different methods have been used to measure economic wellbeing and welfare. One of these methods is using an objective or position scale. The scale uses quantitative indicators visible from a financial status to determine the level of financial wellbeing. For example, consumption of goods, net worth, saving, socioeconomic status, income, number of children and home ownership are accounted for the physical aspects of financial well-being (Van Praag et al., 2003).

Another method is to use subjective measures of financial wellbeing measurement. Subjective wellbeing refers to internal and subjective assessment of the amount of person's financial resources which may be sufficient or insufficient and satisfactory or unsatisfactory. Certain concepts and various tools are used to investigate the subjective wellbeing. Ardelt (1997) knows life satisfaction, happiness, and not feeling discomfort in the life as subjective wellbeing. Brod et al. (1999) described the quality of life as overall subjective assessment of a person from his living in general and specific areas such as social life, finances, job or living situation. George (1993) has used three single-item scales including satisfaction with income, satisfaction with financial status and individual's standard of living consent to measure subjective well-being. Satisfactory with financial position represents an assessment of the overall financial status. Satisfactory with income refers to assessing the amount of income that a person receives or earns regularly. Satisfaction with standards of living is due to an assessment of the quantity and quality of goods and services available or on the market.

In objective and subjective measures of financial well-being, we can say that the objective method will provide more tangible evidence in comparison to the subjective one and it is easier to understand by respondent. In contrast, considering subjective measures cause a more complete assessment of financial well-being. Scales assessing subjective perceptions can provide a more complete understanding of consumer financial behavior. A researcher can identify the views, feelings, and perceptions about ones' financial status, using variables that an individual realizes and provide him with a better symptoms and sign of wellbeing. In this study, we use both measures for financial wellbeing so that we can measure views, feelings and perceptions about their own financial status in addition to considering the quantitative criteria and visible from a financial position.

\subsection{Financial Concerns}

Fear is an unpleasant feeling which appears when losing a value or threatening it. Financial concern appears when one cannot meet his financial needs or his assessment of financial status is not good (Friedman, 1991). Financial concerns usually consist of emotions like fear and anxiety which can negatively affect the human and make positive changes such as finding new jobs and improve the ability to manage the financial issues (Tedeschi \& Calhoun, 2004).

Financial concerns are associated with increased human physical and mental health issues. There is a strong relationship between financial concerns and referral to psychological institutions, depression and suicide (Turkington, 1985). The results of Moser et al. (1984) showed that employed men are 20 percent more susceptible to disease as compared to unemployed men. Fox and Chancey (1998) suggested in their study that financial concerns are negatively related with a sense of personal well-being, self-esteem, satisfaction with marital life and family functioning. Peirce et al. (2002) in their two-year study on 756 unemployed Americans looking for job found that financial concerns and pressure cause reducing physical health rank. They also found that financial concerns may increase the risk of depression and loss of control. Lange and Byrd (1998) achieved similar results in their study on New Zealand students. They have reported that financial problems can make a person feel depressed and concerned and his physical health used up.

The effects of financial concerns in the workplace have been proven in several studies. Studies have shown that financial concerns can result in lost productivity, reduced quality, quantity and efficiency of worker and increased work-related accidents, absenteeism and chance of losing job. Financial concerns can also have 
positive effects such as increased savings directly by employees, reduced absenteeism, improved employee participation, improved quality and productivity (Williams et al, 1996). Negative effect of financial concerns on employee is more than their positive effects in the workplace. Workers who have financial difficulties cannot work with their full capacity and ability and will impose costs for their employers. In a survey by Luther et al. (1997) it was shown that workers' financial difficulties has a huge impact on providing employee productivity and job performance. This research also showed that workers' financial concerns impose high annual cost to the government and financial issues could have a negative impact on the motivation and preparedness for the work as compared with other problems.

\section{Previous Studies}

Different studies on financial literacy, financial concerns and financial wellbeing have been conducted until now that we will briefly state some of them which are closely related to the content of this research in the follow.

Williams et al. (1996) have examined the impact of financial concerns on work productivity. This research was conducted using a field study among 1000 employees. The results showed that employees' financial concerns have a negative impact on their productivity. Also, employees attending consulting classes as well as training finance activities had less financial concerns and higher productivity.

Joo and Grable (2004) have conducted a study aimed at determining factors that influence financial satisfaction. The survey results showed that educational level, financial literacy, risk, financial ability, financial activity and financial pressures have a direct impact on financial satisfaction. The results showed that in high levels of knowledge and financial skills, strengthening the financial behaviors leads to higher levels of financial satisfaction and that financial risk tolerance level and financial pressures have a negative relationship with financial satisfaction. In this study the effect of variables: age, sex, race, marital status, having a home, family income and number of dependents on financial satisfaction was not proved.

Neill et al (2005) have conducted a study aimed at examining the relationship between financial activities, financial wellbeing, and health among 3,121 customers of a financial consulting organization. Their results showed that people with higher income and financial well-being will experience less stress, are more motivated in financial activities, have a better family relationships and are physically and mentally healthier.

Tamimi et al. (2009) examined the impact of financial literacy on financial decisions. Their results showed that the field of individual activities affects financial literacy level and people who invest in the areas of banking and stock have higher level of financial literacy. The survey also showed that men have higher financial literacy and income, age and education level are followed by higher level of financial literacy.

Dvorak and Hanley (2010) in a research subjected with financial literacy and designing retirement plans, have studied the relationship between financial literacy with demographic variables and understanding of retirement plans and documented benefits of the plans, in addition to measuring sample financial literacy. The results of this study showed that the level of financial literacy among people with low income and low education and among women is lower and participating in consultancy and finance training courses leads to increasing financial literacy.

Cude in 2010 examined effective factors on people's financial literacy. His results showed that higher levels of education, risk appetite, higher age, more work experience, family income, parental occupation and attending in training classes will increase financial literacy. In this research it is expressed that people with higher financial literacy are more successful in their business and personal lives. Their financial concerns were well lower and they had longer -term savings and investments and triggered a better future with more long-term vision.

\section{Research Questions and Hypotheses}

The study tries to answer the following question:

1) What is the relationship between financial literacy and financial concerns?

2) What is the relationship between financial wellbeing and financial concerns?

3) What is the relationship between financial literacy and financial wellbeing?

4) What is the relationship between demographic characteristics of age, sex, education, marital status and financial literacy?

5) What is the relationship between demographic characteristics of age, sex, education, marital status and financial wellbeing? 
6) What is the relationship between demographic characteristics of age, sex, education, marital status and financial concerns?

The answers to the questions 1, 2 and 3 determine the relationships between three variables of financial literacy, financial concerns, and financial well-being. Also, the answers to questions 4, 5 and 6 , will clear the relationship between demographic characteristics and these three variables. Following hypotheses are formulated, based on the questions and objectives of the research:

$\mathrm{H}_{1}$ : There is a positive significant relationship between financial literacy and age.

$\mathrm{H}_{2}$ : There is a positive significant relationship between financial wellbeing and age.

$\mathrm{H}_{3}$ : There is a positive significant relationship between financial concerns and age.

$\mathrm{H}_{4}$ : There are significant differences between men and women in financial literacy.

$\mathrm{H}_{5}$ : There are significant differences between men and women in financial concerns.

$\mathrm{H}_{6}$ : There are significant differences between men and women in financial wellbeing.

$\mathrm{H}_{7}$ : There is a significant difference between singles and married financial concerns.

$\mathrm{H}_{8}$ : There is a significant difference between singles and married financial literacy.

$\mathrm{H}_{9}$ : There is a significant difference between singles and married financial wellbeing.

$\mathrm{H}_{10}$ : There is a positive relationship between financial literacy and education of persons.

$\mathrm{H}_{11}$ : There is a positive relationship between financial concerns and education of persons.

$\mathrm{H}_{12}$ : There is a positive relationship between financial wellbeing and education of persons.

$\mathrm{H}_{13}$ : Higher Financial literacy leads to higher economic wellbeing. (Financial literacy has a positive impact on the financial well-being).

$\mathrm{H}_{14}$ : Higher Financial literacy leads to lower financial concerns. (Financial literacy has a negative impact on the financial concerns).

$\mathrm{H}_{15}$ : Higher financial well-being leads to lower financial concerns. (Financial literacy has a negative impact on the financial concerns).

The validity of hypotheses $1,2,3,10,11$ and 12 is investigated using Pearson correlation method. Independent two-sample test based on the $\mathrm{T}$ distribution is used to test the hypothesis, 4, 5, 6, 7, 8 and 9. Last three hypotheses were tested using regression methods.

\section{Research Methodology}

The survey for this study is placed in the area of applicable research depending on its aim, because it focuses on planning to solve a real-world problem and the results can be applied in the real decision-making situations. and from the view point of the method of data collection it can be placed in the field of survey and analysis research, because it studies the characteristics of a statistical population and seeks for analyzing and processing data.

In this research, society is Professor of tow University. This University Are located in Yazd in Iran and has around 300 Professor. In order to calculate sample, we use following formula:

$$
n=\frac{N Z \frac{\alpha^{2}}{2} P(1-P)}{E^{2}(N-1)+Z \frac{\alpha}{2} P(1-P)}
$$

In which the reliability level $95 \%$ and the estimated error was 0.07 . $(\mathrm{Z} \alpha / 2=1.96, \mathrm{P}=0.5)$. According to the calculation, the number of the samples was 103 and was selected by Simple random sampling.

\subsection{Measuring Financial Literacy}

The Chen and Volpe (1998) questionnaire was used in order to measure financial literacy of individuals. This questionnaire has been trying to consider the most important personal finance factors in the measurement of financial literacy. These factors include: general knowledge of finance including 9 questions, savings and loan including 9 questions, investment including 6 questions, insurance including 7 questions and financial decisions, financial opinions and financial training consisted of 8 questions. A five-option Likert scale was used in the questionnaire so that the score 1 represents the worst and 5 indicates the best situation for an individual upon 
that question.

\subsection{Measuring Financial Wellbeing}

A questionnaire designed by Prawitz et al. (2006) has been used to measure respondents' financial wellbeing. The questionnaire consisted of eight questions. A ten-option scale was designed and respondents are asked to choose the most appropriate score on their own position so that the lowest score indicates the financial pressure and the highest score is an indicator of financial well-being.

\subsection{Measuring Financial Concerns}

The questionnaire used in this study to measure respondents' financial concerns was designed according to Fox \& Chancey (1998), Scannell (1990), Schinittgrund \& Baker (1983) and Sumarwan \& Hira (1993) studies and used in Joo (1998), Bagwell (2000) and Kim and Garman (2003) studies. The questionnaire consisted factors: satisfaction with financial status, debts and saving, enough income, and investment. The questionnaire included four items: "I am satisfied with my financial status.", "My income is enough to pay my monthly expenses", "I'm not worried about my debt", and "I am satisfied with the amount of money I save for retirement and investment". These four questions were presented in a Likert scale of five options and respondents rate their agreement with the terms with expressions one to five.

\subsection{Validity and Reliability of Questionnaire}

This three Measuring tools included in the form of a questionnaire and at the beginning of the questionnaire questions related to personal variables were discarded. The questions on education level and marital status was designed as option; the options for education level include (1) associated degree, (2) BA, (3) MA and (4) PhD and include (1) single and (2) married for the marital status. Respondents have indicated their age in years-old and gender in a two-item option. After designing the questionnaire, its reliability and validity was tested.

In order to check the validity of the questionnaire, several theories of recovery which were suggested by some teachers, were intended in the final design. Cronbach's alpha was calculated to test the reliability of the questionnaire so that the alpha coefficient of the questionnaire was $81 \%$ for the financial literacy, $89 \%$ for the financial concerns and $79 \%$ for the financial well-being.

\section{Data Analysis and Results}

Data were analyzed using SPSS statistical software. Results of descriptive statistics are presented in Table 1.

Pearson correlation test was used in order to check the validity of hypothesis 1,2 and 3 . The results of these tests are given in Table 2. This table shows that two variables of financial wellbeing and financial literacy is associated with the age of respondents (financial literacy, $r=0 / 534, p \leq .01$; financial well-being, $r=0 / 541, p$ $\leq .01$ ). These results are consistent with the hypothesis 1 and 2 . Since the correlation coefficient is positive for the variables of financial literacy and financial well-being, thus the validity of the first two hypotheses is confirmed with $99 \%$ confidence. The results of correlation analysis reject the relationship between age and financial concerns so, the validity of third hypothesis is rejected at the significance level of $95 \%(r=0 / 021, p$ $\geq .05)$.

Table 1. Respondents characteristics

\begin{tabular}{|c|c|c|}
\hline variable & $\mathrm{SD}$ & $\min$ \\
\hline \multirow[t]{2}{*}{ age } & $11 / 89$ & 41.05 \\
\hline & NO. & Percentage \\
\hline \multicolumn{3}{|l|}{ Gender } \\
\hline Female & 15 & $14 / 6$ \\
\hline Male & 88 & $85 / 4$ \\
\hline \multicolumn{3}{|l|}{ education level } \\
\hline associated degree & 3 & $2 / 9$ \\
\hline Bachelor of Science & 10 & $9 / 7$ \\
\hline Master of Science & 28 & $27 / 2$ \\
\hline $\mathrm{PhD}$ & 62 & $60 / 2$ \\
\hline
\end{tabular}

To test the validity of hypotheses 4,5 and 6 , the $t$ test was used for two independent samples. The results of these tests are given in Table III. Results show that at the confidence level of $95 \%$, assumption of existing differences in financial literacy for men and women is confirmed. Since the average financial literacy scores of 
men is higher than women, it can be concluded that financial literacy among men is higher than financial literacy among women. There are also significant differences between financial concerns of men and women at the confidence level of $95 \%$ which is confirmed and hypothesis 5 is also accepted. Since the mean scores of financial concerns of men are more than women so, men are concerned about financial issues more than women. For the sixth hypothesis, existence of a significant difference in the financial well-being scores of men and women will be rejected at $95 \%$ confidence level.

Table 2. Correlation analysis results

\begin{tabular}{|c|c|c|c|c|c|c|c|}
\hline variable & $\min$ & SD & 1 & 2 & 3 & 4 & 5 \\
\hline age & 41.05 & $11 / 89$ & & & & & \\
\hline education level & 3.01 & .99 & & & & & \\
\hline Financial Literacy & 134 & 32.8 & $0 / 534 * *$ & $0 / 444 *$ & 1 & & \\
\hline financial wellbeing & 58.8 & 20.5 & $0 / 241 * *$ & $0 / 223^{*}$ & $0 / 263^{*}$ & 1 & \\
\hline financial concerns & 15.3 & 3.8 & $0 / 021$ & $0 / 173$ & 0/134* & $0 / 11 *$ & 1 \\
\hline
\end{tabular}

$\mathrm{P}^{*} \leq 0.05 ; \mathrm{p}^{* *} \leq 0.01$.

The validity of the hypotheses 7, 8 and 9 is investigated using the t-test for two independent samples to examine existence of differences between the two groups. With regard to the statistics $(t=2.05)$ and $(p=0 / 019)$, which is less than 0.05 , the equal means of single and married financial literacy were rejected at the $95 \%$ confidence level of zero hypothesis and seventh hypothesis is confirmed. Also, since the statistic $(t=0.022)$ and $(p=0 / 981)$ which is less than 0.05 , equal means of single and married financial literacy were accepted at the $95 \%$ confidence level of zero hypothesis and eighth hypothesis is rejected. The ninth hypothesis is rejected at the $95 \%$ confidence level because $(\mathrm{p}=0.407)$ is greater than 0.05 .

Table 3. Independent samples test

\begin{tabular}{|c|c|c|c|c|c|c|c|c|c|c|}
\hline \multicolumn{6}{|c|}{ Two groups of males and females } & \multicolumn{5}{|c|}{ Two groups of single and married } \\
\hline & \multicolumn{2}{|c|}{$\min$} & \multirow[t]{2}{*}{$\mathrm{t}$} & \multirow[t]{2}{*}{$\mathrm{df}$} & \multirow[t]{2}{*}{ sign } & \multicolumn{2}{|c|}{ Min } & \multirow[t]{2}{*}{$\mathrm{t}$} & \multirow[t]{2}{*}{$\mathrm{df}$} & \multirow[t]{2}{*}{ sign } \\
\hline & Male & Female & & & & Married & Single & & & \\
\hline literacy & 152 & 116 & 2.05 & 92 & $0 / 021$ & 152 & 116 & 2.05 & 92 & $0 / 019$ \\
\hline concerns & 16 & 14.6 & 2.19 & 92 & $0 / 03$ & 16 & 14.6 & .022 & 92 & $0 / 981$ \\
\hline Wellbeing & 62.6 & 55.2 & .814 & 92 & $.0 / 418$ & 62.6 & 55.2 & .834 & 92 & $.0 / 407$ \\
\hline
\end{tabular}

In order to examine whether scores of financial literacy and financial concern are associated with financial education, the Pearson's correlation test was used. In order to determine the level of education of respondents, the interval scale is used. So that score 1, 2, 3 and 4 was considered for the associate degree, BA, MA, and 4, respectively. The correlation test results are shown in Table 2 . This test shows that the level of education is related to financial literacy $(\mathrm{r}=0 / 444)$ and financial well-being $(\mathrm{r}=0 / 223)$ at the $95 \%$ confidence level. But the test has rejected the relationship between financial concerns and financial education (sing $\geq 0.05)$ so, the hypothesis 11 is rejected and hypotheses 10 and 12 are accepted.

Table 4. Result of regression analysis

\begin{tabular}{lllcc}
\hline \multicolumn{1}{c}{ Hypothesis } & Depend variable & \multicolumn{2}{c}{ Independent variable } \\
\hline & & & amount & Sign \\
Regression test for $\mathrm{H}_{13}$ & Financial wellbeing & Age & 1.3 & .04 \\
& & education level & 2.54 & .0321 \\
& & Financial literacy & .93 & .00 \\
\hline \multirow{2}{*}{ Regression test for $\mathrm{H}_{14}$ and $\mathrm{H}_{15}$} & Financial concerns & Financial literacy & .618 & .001 \\
& & Financial wellbeing & .733 & .005 \\
\hline
\end{tabular}


In order to check the hypotheses 13,14 and 15, the regression test was performed. Because correlation analysis results proved the relationship between financial literacy with education and age, age and education were used as a control variable in regression testing to verify the hypothesis 13 . So, in the first step of the regression model these two variables were entered into the model and then the variable financial literacy was entered. For testing the validity of hypotheses 14 and 15, the financial literacy and financial wellbeing were used as independent variables and financial concern as the dependent variable in the regression analysis. The variables financial literacy and financial well-being were entered into the model in the first and the second step of the test, respectively and their impact on financial concerns was measured. Results of regression analysis indicated that the hypotheses 13 and 14 are confirmed at the $99 \%$ of confidence level and the hypothesis 15 is confirmed at the $95 \%$ confidence level.

\section{Conclusions and Discussion}

The relationship between financial literacy and financial wellbeing, financial literacy and financial concerns, and financial well-being and financial concerns were assessed in this study. Also, the role of demographic characteristics including age, sex, marital status and education level on the score change of financial wellbeing, financial literacy and financial concerns were investigated. The results revealed several important points. First, there is a positive relationship between the age and variables of financial wellbeing and financial literacy, marital status and sex and the financial literacy variable, and education level and financial well-being variable and financial literacy. Second, a higher level of financial wellbeing is followed by financial literacy. Third, higher financial literacy leads to less financial concerns. Finally, higher financial well-being reduces financial concerns.

Different results have been shown, studying the effects of psychological variables on financial wellbeing, financial literacy and financial concerns. Regarding the relationship between age and these three variables in researches Malone et al. (2010) and Cude (2010) a negative correlation between age and financial concerns is demonstrated and also it has been expressed that less financial concerns is followed by older age. In the research by Kim and Garman (2003) and Kim et al (2003) the positive relationship between age and financial concerns is concluded. In the researches Cude (2010), Lusardi et al. (2010), Kindle (2010), Volpe et al. (2002) and Tamimi and Kalli (2009) a positive relationship between age and financial literacy has been demonstrated. Joo and Grable (2004) have studied the relationship between age and financial satisfaction. The results of this study have declined the relationship between age and financial satisfaction. This study found a positive relationship between age and the financial well being, and age and financial literacy but, it has rejected the link between age and financial concerns.

Regarding the relationship between education level and these three variables, researches Malone et al. (2010), Cude (2010), Lusardi et al. (2010), Dvorak and Hanley (2010), Peng et al. (2007), Volpe et al. (2002 ), Tamimi and Kalli (2009) (2009), Joo and Grable (2004) and Chen and Volpe (1998) have confirmed the positive relationship between education and financial literacy. Kim and Garman (2003) found a positive relationship between education and financial concerns and Cude (2010) concluded that higher education leads to less financial concerns. Joo and Grable (2004) have proven a positive relationship between education and economic wellbeing in their study but, in this study, the relationship between education level and financial concerns have been rejected.

Regarding the relationship between gender and these three variables Kim and Garman (2003) in a research concluded that men are more concerned than women about financial issues. The relationship between gender and financial well-being is denied in Joo and Grable (2004) survey. Lusardi et al. (2010), Dvorak and Hanley (2010), Peng et al. (2007), Volpe et al. (2002) and Chen and Volpe (1998) concluded higher financial literacy in men, and Kindle (2010) has rejected the relationship between financial literacy and gender. Our results showed that men are better than women in financial literacy but the existence of relationship between gender and financial literacy as well as financial concerns is rejected.

Regarding the relationship between these three variables and marital status; in the survey by Joo and Grable (2004) the relationship between marital status and financial well-being is denied and in the study by Volpe et al. (2002) the relationship between marital status and financial literacy was demonstrated and it is stated that married individuals are more financial literate. Our study shows that married people are more financial literate, but the relationship between marital status and financial wellbeing and financial concerns have been rejected.

As mentioned before, several studies provide different results from the relationship between demographic variables with the variables financial literacy, financial concerns and financial wellbeing. There is one explanation for this difference may be due to differences in time and place of the investigation. The change in 
the time and place can affect the definition of people from financial wellbeing and financial concerns and their relationship with demographic variables. Economic conditions, technology, values, culture and norms change among communities, Changing location and time, and cause changing perceptions such as satisfaction with income and savings, needs, safety, comfort and satisfaction with the distribution of income and bonuses. As in the past that the meaning of financial well-being was happiness or satisfaction with one's or financial position or assets but at the present the individual's perception of material and spiritual aspects of one's financial situation has meant changing, improving people's living standards Joo (1998).

This survey showed in studying the relationship between the three variables of financial literacy, financial concerns, and financial well-being that higher financial wellbeing and higher financial concerns may be followed by higher financial literacy also increased financial wellbeing leads to reduced financial concerns.

The results of the study is compatible with the results of Kim et al. (2003), Neill et al (2005) who have confirmed the negative impact of the financial wellbeing on financial concerns. The results of this research is also compatible with the research by Tamimi and Kalli (2009) who proved the positive impact of financial literacy on financial wellbeing and with the research by Joo and Grable (2004), Williams et al. (1996) and Cude (2010) who have demonstrated the negative impact of financial literacy on financial concerns.

Interactions of living and working, losses, benefits and daily events will largely depend on personal financial management. Individual's financial management abilities in organizational and personal life is also due to high financial literacy. Financial literacy provides the background of one's successful participation in economic activities through increased savings, correct purchasing decision, proper investing, asset management, employing insurance, debt, credit management and enhances the financial well-being. On the other hand, the financial literacy cause reduced financial concerns through improved ability to meet the needs and provide compatibility between financial income and expenses. High financial literacy also makes human assessing their financial position reasonably, understanding economic situation, and being less stressful and worried in financial issues.

In addition to the restrictions in the field and data collection methods, the researcher in this study was associated with limitations in the precise measurement of financial literacy, financial concerns, and financial well-being. No questionnaire was provided in Iran until now so that it's cultural, social and economic situation has been considered in its design. The questionnaire used in this study has been designed in other countries. The researchers have translated the questionnaire and used their reliability and validity assessment. These types of questions can affect the validity of the results. In this regard, it is suggested to design a questionnaire to assess the accuracy of these three variables considering the social, cultural and economic situation of Iran and other countries in a comprehensive study. Also it is suggested for future research to conduct such researches in other classes and compare its results with ours and investigate the relationship between financial literacy, financial wellbeing and financial concerns with psychological characteristics. Finally, it is suggested to conduct a survey in order to study major causes of financial concerns and the proposed solutions to resolve them.

\section{References}

Al-Tamimi, H. (2006). Factors influencing individual investor behavior: an empirical study of the UAE financial markets. The Business Review, 5, 225-32.

Amato, P., \& Keith, B. (1991). Parenta divorce adult wellbeing. Journal of Marriage and Family, 53, 43-58. http://dx.doi.org/10.2307/353132

Ardelt, M. (1997). Wisdom and satisfaction in old age. Journal of Gerontology, 52(1), 15-27.

Brod, M., Stewart, A. L., \& Sands, L. (1999). Conceptualization and measurement of quality of life in dementia. Gernotologist, 39(1), 25-35. http://dx.doi.org/10.1093/geront/39.1.25

Bagwell, D. C. (2000). Work and personal financial outcomes of credit counseling clients. Unpublished doctoral dissertation, Virginia Polytechnic Institute and State University, Blacksburg.

Bernheim, D., \& Daniel, G. (2003). The Effects of Financial Education in the Workplace: Evidence from a Survey of Households. Journal of Public Economics, 87, 1487-1519. http://dx.doi.org/10.1016/S0047-2727(01)00184-0

Brennan, P. Q. (1998). Personal finance education: What employees need and want to know. Personal Finance and Worker Productivity, 2(1), 68-74.

Brenner, M. H. (1973). Mental illness and the economy. Cambridge, MA: Harvard University Press.

Brod, M., Stewart, A. L., Sands, L., \& Walton, P. (1999). Conceptualization and measurement of quality of life 
in dementia: The dementia quality of life instrument (DQOL). Gerontologist, 39, 25-35. http://dx.doi.org/10.1093/geront/39.1.25

Byrne, A. (2007). Investment employees saving and investment decisions in defined contribution pension plans: survey evidence from the UK. Financial Services Review, 16, 19-40.

Champoin, H. R. (2001). Totally integrated employee benefits. Public Personal Management, 30(3), 287-302.

Chen, H., \& Volpe, R. (1998). An analysis of personal financial literacy among college students. Financial Services Review, 7(2), 107-28. http://dx.doi.org/10.1016/S1057-0810(99)80006-7

Cude, B. J. (2010). Financial Literacy. The Journal of Consumer Affairs, 44(2).

Cude, B., Frances, L., Angela, L., Kaci, M., Emily, L., Loren, M., \& Krisanna, M. (2006). College Students and Financial Literacy: What They Know and What We Need to Learn. Proceedings of the Eastern Family Economics and Resource Management Association, 102-109. http://dx.doi.org/10.1111/j.1745-6606.2010.01168.x

Danes, S. M., \& Hira, T. K. (1987). Money management knowledge of college students. The Journal of Student Financial Aid, 17(1), 4-16.

Danes, S. M., \& Haberman, H. R. (2007). Teen financial knowledge, self efficacy and behavior: A gendered view. Financial Counseling and Planning Journal, 18, 48-60.

Deviney, S., \& Solomon, J. (1995). Gender difference in interment income. Journal of Women and Aging, 7(4), 83-100. http://dx.doi.org/10.1300/J074v07n04_07

Dvorak, T., \& Hanley, H. (2010). Financial Literacy and the Design of Retirement Plans. Union College. Retrieved from http://minerva.union.edu/dvorakt/.../dvorak\%20hanley\%20revision.pdf

Fergusson, D. M., Horwood, L. J., \& Beautrais, A. L. (1981). The measurement of family material wellbeing. Journal of Marriage and Family, 43(3), 715-725. http://dx.doi.org/10.2307/351771

Fish, 1. S., \& Osborn, J. L. (1992). Therapist views of family life: A Delphi study. Family Relation, 41, 409-416. http://dx.doi.org/10.2307/585583

Fox, G. L., \& Chancey, E. (1998). Sources of economic distress: Individual and family outcomes. Journal of Family Issues, 19(6), 725-749. http://dx.doi.org/10.1177/019251398019006004

Fox, J., Bartholomae, S., \& Lee, J. (2005). Building the case for financial education. The Journal of Consumer Affairs, 39(1), 195-214. http://dx.doi.org/10.1111/j.1745-6606.2005.00009.x

Friedman, D. (1991). Linking Work-Family Issues to the Bottom Line. The Conference Board, New York.

Galambos, N. L., \& Silbereisen, R. K. (1987). Income change, parental life outlook, and adolescent expectations for job success. Journal of Marriage and the Family, 49, 141-149. http://dx.doi.org/10.2307/352678

Garman, E. T., Leech, I. E., \& Grable, J. E. (1996). The negative impact of employee poor personal financial behaviors on employers. Financial Counseling and Planning, 7, 157-168.

Garman, E. T., Kim, J., Kratzer, C. Y., Brunson, B. H., \& Joo, S. (1998). Workplace financial education improves personal financial wellness. Financial Counseling and Planning, 10(1), 79-88.

Garman, E. T., \& Forgue, R. E. (2000). Personal finance: the human resource manager: Caught in the middle. CUPA Journal, 45(1), 33-35.

George, L. K. (1993). Sociological perspective on life transitions. Annual Review of Sociology, 19, 353-373. http://dx.doi.org/10.1146/annurev.so.19.080193.002033

Godfrey, N. (2006). Making Our Students Smart about Money. Education Digest, 71(7), 21- 26.

Goldsmith, E. B. (2000). Resource management for individual and family. Belmont, CA: Wadsworth learning.

Hayhoe, C., Leach, 1., Turner, P., Bruin, M., \& Lawrence, F. (2000). Difference in spending Habits and credit card use of college students. Journal of Consumer Affairs, 34, 113-133. http://dx.doi.org/10.1111/j.1745-6606.2000.tb00087.x

Hogarth, M. (2006). Financial Education and Economic Development. International Conference hosted by the Russian G8 Presidency in Cooperation with the OECD.

Huston, S. (2010). Measuring Financial Literacy. Journal of Consumer Affairs, 44, 296-316. http://dx.doi.org/10.1111/j.1745-6606.2010.01170.x 
Jacob, K., Hudson, S., \& Bush, M. (2000). Tools for survival: An analysis of financial literacy programs for lower-income families. Chicago: Woodstock Institute.

Jacobs, B. I. (2009). Tumbling tower of Babel: subprime securitization and the credit crisis. Financial Journal, 65, 17-30. http://dx.doi.org/10.2469/faj.v65.n2.6

Joo, S. (1998). Personal financial wellness and worker productivity. Unpublished doctoral dissertation, Virginia Polytechnic Institute and State University, Blacksburg.

Joo, S., Grable, J., \& Bagwell, D. (2003). Credit card attitudes and behaviors of college students. College Student Journal, 37, 405-419.

Joo, S., \& Grable, J. E. (2004). An exploratory framework of the determinants of financial Satisfaction. Journal of Family and Economic Issues, 25(1), 162-171. http://dx.doi.org/10.1023/B:JEEI.0000016722.37994.9f

Kim, J. (1999). Financial satisfaction, personal finance-work conflict, and work outcomes: Pay satisfaction, organizational commitment, and productivity. Proceedings of the Association for Financial Counseling and Planning Education Annual Conference, Scottsdale, AZ.

Kim, J., \& Garman, E. T. (2003). Financial Stress and Absenteeism: An Empirically Derived Research Model. Financial Counseling and Planning, 14(1).

Kim, J. E., Thomas, G., \& Benoit, S. (2003). Relationships among Credit Counseling Clients' Financial Wellbeing, Financial Behaviors, Financial Stressor Events, and Health. Financial Counseling and Planning, 14(2).

Kim, J. (2007). Workplace financial education program: Does it have an impact on employee's personal finances. Journal of family and Consumer Science, 99(1).

Kindle, P. A. (2010). Student perceptions of financial literacy: Relevance to practice. Journal of Social Service Research, 36(5), 470-481. http://dx.doi.org/10.1080/01488376.2010.510951

Lange, C., \& Byrd, M. (1998). The relationship between perceptions of financial distress and feelings of psychological well-being in New Zealand university students. International Journal of Adolescence and Youth, 7, 193-209. http://dx.doi.org/10.1080/02673843.1998.9747824

Leach, L. J., Hayhoe, C. R., Turner, P. R. (1999). Factors affecting perceived economic wellbeing of college students: A gender perspective. Financial Counseling and Planning, 10(2), 11-23. http://dx.doi.org/10.1111/j.1540-4560.1988.tb02089.x

Leech, M. (1988). Economic recession and mental health: Some conceptual issues. Journal of Social Issues, 44(4), 13-23.

Lorenz, F. O., Conger, R. D., \& Montague, R. (1994). Doing worse and feeling worse: Psychological consequences of economic hardship. Social Institutions and Social Change, 167-186.

Lusardi, A. (2004). Savings and the Effectiveness of Financial Education. In Olivia S. Mitchell and Stephen Utkus (Eds.), Pension Design and Structure: New Lessons from Behavioral Finance (pp. 157-184). Oxford: Oxford University Press. http://dx.doi.org/10.1093/0199273391.003.0009

Lusardi, A., Ricardo, C., \& Erin, K. (2001). Savings of Young Parents. Journal of Human Resources, 36, 762-794. http://dx.doi.org/10.2307/3069641

Lusardi, A., Punam, K., \& Adam, K. (2008). New Ways to Make People Save: A Social Marketing Approach. In Annamaria Lusardi (Ed.), Overcoming the Saving Slump: How to Increase the Effectiveness of Financial Education and Saving Programs (pp. 209-236). Chicago: University of Chicago Press.

Lusardi, A., \& Olivia, S. M. (2006). Financial Literacy and Planning: Implications for Retirement Wellbeing. Working Paper, Pension Research Council, Wharton School, University of Pennsylvania.

Luther, R. J., Grasmick, H. G., Morgan, C. S., \& Wenk, D. (1992). The effects of gender, family satisfaction, and economic strain on psychological well-being. Family Relations, 41, 440-446. http://dx.doi.org/10.2307/585588

Lusardi, A., Mitceli, O. S., \& Curto, V. (2010). Financial Literacy among the Young. The Journal of Consumer Affairs, 44(2). http://dx.doi.org/10.1111/j.1745-6606.2010.01173.x

Malone, K., Susan, D. S., Jan, W., \& Peter, F. K. (2010). Perceptions of Financial Well-Being among American Women in Diverse Families. Family Economics Issue, 31, 63-81. http://dx.doi.org/10.1007/s10834-009-9176-5 
Maditinos, D., Sevic, Z., \& Theriou, N. (2007). Investors' behavior in the Athens stock exchange. Studies in Economics and Finance, 24, 32-50. http://dx.doi.org/10.1108/10867370710737373

McGregor, S. L., \& Goldsmith, E. B. (1998). Expanding our understanding of quality of life. Journal of Family and Science, 90(2), 2-6.

Mirshekary, S., \& Saudagarah, S. (2005). Perceptions and characteristics of financial information users in developing countries: evidence from Iran. Journal of International Accounting, Auditing and Taxation, 14, 33-54. http://dx.doi.org/10.1016/j.intaccaudtax.2005.01.001

Monetary Authority of Singapore. (2005). Quantitative Research on Financial Literacy Levels in Singapore, report, July.

Monticone, Ch. (2010). How Much Does Wealth Matter in the Acquisition of Financial Literacy. Journal of Consumer Affairs, 44, 403-422. http://dx.doi.org/10.1111/j.1745-6606.2010.01175.x

Moore, R., Mao, Y., Zhang, J., \& Clarke, K. (1997). Economic burden of illness in Canada, 1993. Laboratory Centre for Disease Control. Health Canada. Ottawa.

Neill, B., Xiao, J. J., \& Benoit Sorhaindo, E. T. (2005). Financially Distressed Consumers: Their Financial Practices, Financial Well-being, and Health. Financial Counseling and Planning, 16(1).

Nunnally, J. C. (1978). Improving Financial Literacy. OECD Publishing, Paris.

Pearlin, L. I., Menaghan, E. G., Lieberman, M. A., \& Mullan, J. T. (1981). The stress process. Journal of Health and Social Behavior, 22, 337-356. http://dx.doi.org/10.2307/2136676

Peirce, R. S., Frone, M. R., Russell, M., \& Cooper, M. L. (1994). Relationship of financial strain and psychosocial resources to alcohol use and abuse: The mediating role of negative affect and drinking motives. Journal of Health and Social Behavior, 35, 291-308. http://dx.doi.org/10.2307/2137211

Peng, T. M., Bartholomae, S., Fox, J. J., \& Cravener, G. (2007). The impact of personal finance education delivered in high school and college courses. Journal of Family and Economic, 28, 265-284. http://dx.doi.org/10.1007/s10834-007-9058-7

Porter, N. M. (1990).Testing a model of financial wellbeing. Financial Counseling and Planning, 4, 135-164.

Prawitz, A. D., Thomas Garman, E., Sorhaindo, B., Barbara O’Neill, K. J., \& Drentea, P. (2006). In Charge Financial Distress/Financial Well-Being Scale: Development, Administration, and Score Interpretation. Financial Counseling and Planning, 17, 34-50.

Rantakeisu, U., Starrin, B., \& Hagquist, C. (1999). Financial hardship and shame: A tentative model to understand the social and health effects of unemployment. British Journal of Social Work, 29(6), 877-901. http://dx.doi.org/10.1093/bjsw/29.6.877

Remund, D. L. (2010). Financial Literacy Explicated: The Case for a Clearer Definition in an Increasingly Complex Economy. Journal of Consumer Affairs, 44, 276-295. http://dx.doi.org/10.1111/j.1745-6606.2010.01169.x

Redmond, K. (2007). Bankruptcy filings plunge in calendar year 2006. Retrieved from http://www.uscourts.gov

Scannell, E. (1990). Dairy farm families' financial management. Financial Counseling and Planning, 1, 133-146.

Schnittgrund, K. P., \& Baker, G. (1983). Financial management of low income urban families. Journal of $\begin{array}{lllll}\text { Consumer Studies } \text { Home 261-270. } & \text { Economics, }\end{array}$ http://dx.doi.org/10.1111/j.1470-6431.1983.tb00628.x

Strumpel, B. (1976). Economic means for human needs. Personal Finance and Worker Productivity, 2, 68-74.

Stokes, G., \& Cochrane, R. (1984). A study of the psychological effects of redundancy and unemployment. Journal of Occupational Psychology, 57, 309-22. http://dx.doi.org/10.1111/j.2044-8325.1984.tb00171.x

Sumarwan, U., \& Hira, T. K. (1993). The effects of perceived locus of control and perceived income adequacy on satisfaction with financial status of rural households. Journal of Family and Economic Issues, 14, 343-364. http://dx.doi.org/10.1007/BF01013984

Tamimi, A. H., \& Kalli, A. B. (2009). Financial literacy and investment decisions of UAE investors. The Journal of Risk Finance, 10(5).

Tedeschi, R. G., \& Calhoun, L. G. (2004). Posttraumatic growth: Conceptual foundations and empirical 
evidence. Psychological Inquiry, 15, 1-18. http://dx.doi.org/10.1207/s15327965pli1501_01

Titus, P. M., Fanslow, A. M., \& Hira, T. K. (1998). Net worth and financial satisfaction as a function of household money manager competition. Economic Research Journal, 17(4), 309-318.

Turkington, C. (1985). Farmers strain to hold the line as crisis uproots mental health. American Psychological Association Monitor, 16(4), 26-27.

Van Praag, B. M. S., Frijters, P., \& Ferrer-i-Carbonel, A. (2003). The anatomy of subjective well-being. Journal of Economic Behavior and Organisation, 51, 29-49. http://dx.doi.org/10.1016/S0167-2681(02)00140-3

Vitt, L. A., \& Anderson, C. (2001). Personal finance and the rush to competence: Financial literacy in the U.S. Middleburg, VA: Fannie Mae Foundation.

Vitt, L. A., Anderson, C. A., Kent, J., \& Lyter, D. (2000). Personal finance. Washington, DC: fannies mea foundation.

Volpe, R., \& Chen, H. L. (2006). An analysis of the importance of personal finance topics and the level of knowledge possessed by working adults. Financial Services Review, 15, 81-98.

Volpe, R., Chen, H., \& Pavlicko, J. (1996). Personal investment literacy among college students: a Survey. Financial Practice and Education, 6, 86-94.

Volpe, R., Kotel, J., \& Chen, H. (2002). A survey of investment literacy among online investors. Financial Counseling and Planning, 13, 1-13.

Weagley, \& Moore. (1997). Employee benefits: Knowledge and satisfaction. Personal Finance and Worker Productivity, 1, 150-159.

Williams, F. 1. (1983). Money income, no money income, and satisfaction as determinants of perceived adequacy of income. Paper presented at the perceived economic wellbeing symposium, Urbana.

Williams, F. L., Virginia, H., \& Sheran, C. (1996). Financial Concerns and Productivity. Financial Counseling and Planning, 7. 